RESEARCH NOTE

\title{
Assessing Employment Risk: New Dimensions in the Measurement of Unemployment ${ }^{1}$
}

\author{
John Shields Ryerson University \\ Susan Silver Ryerson University \\ Sue Wilson Ryerson University
}

The contemporary era has increasingly come to be characterized as a 'risk society' (Beck, 1992). This idea underlies a growing sense of insecurity that large segments of the population feel and experience. Much of this increased insecurity is the consequence of global economic restructuring and the retrenchment of the 'social security state' (Hahnel, 2005; Eliott and Atkinson, 1998; and Wolman and Colamosca, 1997). The problem of growing economic risk was the subject of a recent International Labour Organization (ILO) report which concluded that economic security was out of reach for the majority of the globe's workers creating a 'world of anxiety and anger' (2004a). Even in the developed world neoliberal inspired policies and restructuring have enhanced economic vulnerability as the divide between 'haves' and 'have-nots' grows (Burke, Mooers \& Shields, 2000). "Work risk" is an important, if not central, facet of economic risk.

We wish to address one dimension of "work risk", namely the threat of unemployment. Unemployment is important because working for pay is the primary way in which most individuals and families are able to achieve a measure of economic security and are able to more fully ground themselves in their societies thus forestalling social exclusion. However, our comprehension of the full extent of unemployment is limited by our reliance on conventional measures.

High unemployment is a global issue. According to the ILO $30 \%$ of the world's labour force is either unemployed or seriously underemployed. By the end of the 1990s, there were 140 million unemployed workers worldwide (ILO, 1998: 1), and by 2003 this had climbed to 185.9 million or some $6.2 \%$ of the global labour force, "the highest

${ }^{1}$ The research reported here was supported by a Social Sciences and Humanities Research Council grant. We would also like to thank Philip Giles from Statistics Canada for his technical support, though the interpretation of the data are those of the authors. 


\section{Assessing Employment Risk: New Dimensions in the Measurement of Unemployment}

unemployment figure ever recoded by the ILO" (ILO 2004b: 10). The number of working poor globally, i.e., "workers not earning enough to keep themselves and their families above the US\$1 a day poverty line", rested at 550 million, also a first (ILO 2003: 8). By the mid-1990s, in the OECD there were in excess of 35 million unemployed workers - 10 million more than the $1980 \mathrm{~s}$ - and an estimated 15 million more who had given up looking for work. An additional 30 to 40 million could be added to the total if the underemployed were counted (Elliott and Atkinson, 1999: 8; Commission for Labor Cooperation, 1997: 8; and OECD, 1994: 9). After a period of employment recovery in the later half of the 1990s unemployment increased significantly in the industrialized countries between 2000 and 2002, resting at 7.4\% in 2001 (ILO 2003: 10). Each year about 47 million new job seekers enter the global labour market. In the words of Richard Barnet, "we are swimming in a global labor pool" (1993: 48-49). The ILO reports that "in most parts of the world the growth of new employment opportunities still remains insufficient to productively employ those who have lost jobs due to restructuring and the new entrants into the labour force" (2001: 1).

Canada has also been subject to these broad shifts. From the 1950s until the early 1970s, unemployment in Canada was maintained at around 4\%, except during short recessionary dips. At this level of unemployment we were close to the official definition of "full" employment. While the Keynesian demand for full-employment was never fully embraced the Canadian Government was committed to maintaining high and stable levels of employment (McBride, 1992: 4). This public policy commitment to minimizing unemployment has all but disappeared. In fact, by 1994 the Canadian Federal Department of Finance conceded that the core rate of unemployment "that portion of the labour force that is no longer able to be reabsorbed in the economy after a recovery" had increased from about $4 \%$ to $8 \%$ or more (Government of Canada, 1994: 19-20). In fact, the average rate of unemployment in Canada was 9.1\% from 1976 to 2001 (Bennett, 2001: 4). Of course, government acceptance of significantly higher levels of unemployment followed the displacement of the Keynesian policy paradigm by a neoliberal model. High unemployment and, more generally, increased levels of job insecurity under the neoliberal world view was important for facilitating structural adjustment, including labour market restructuring and the taming of labour's power (Yates, 2003).

Unemployment rates have long been one of the standard tools for measuring economic security as they provide an important gauge of labour force attachment, income generation, and inclusion. However, because unemployment rates are generally calculated and reported as snapshots of the proportion of the population that is unemployed at a point in time, they do not tell the complete story. Part of the problem has been that the surveys used for calculating unemployment, like the Canadian Labour Force Survey (LSF), are limited in their measurement capabilities. They are only able to determine what happens 


\section{Assessing Employment Risk: New Dimensions in the Measurement of Unemployment}

to individuals at static set points in time. Newer and more sophisticated surveys like the Survey of Labour and Income Dynamics (SLID), open up new ways for looking at unemployment.

SLID is a longitudinal data set created by Statistics Canada and designed to measure changes in the socio-economic well-being of Canadians. This survey was started in 1993 and follows panels of individuals for six year periods. SLID uses a large representative sample of more than 60,000 individuals aged 16 to 69. SLID enables us to create a more comprehensive picture of the unemployment experience. For example, we can measure the number of Canadians who were unemployed at any point during the preceding year. The LFS only measures the number of Canadians who are unemployed at the time of the survey. In short, by using SLID data we are able to calculate the proportion of those in the labour force who were unemployed at some point during the year, giving us a deeper measure of the Canadian unemployment experience.

When we compare "official unemployment rates", as reported by Statistics Canada, with the percentage of Canadians who were actually unemployed for some or all of the year, the "lived unemployment rate", which the SLID survey allows us to construct, we can uncover deeper dimensions of how Canadians actually experience unemployment. The measure reveals that those Canadians that are directly touched by unemployment within a one year period are, in fact, twice as high as the "official" annual averages. For example, between 1993 and $2001^{2}$ the "lived unemployment rate" stood at $19.9 \%$, fully one fifth of the labour force, more than double the average "official unemployment rate" for this time period that stood at $8.7 \%$ (see Table 1). Consequently, the risk of joblessness is far more widespread than simple "official unemployment rates" appear to suggest.

Also it is instructive to examine the effects of measuring unemployment in these two ways on gender. The overriding pattern between 1993 and 2001 has been for male "official unemployment rates" to be higher than that of female rates suggesting greater male vulnerability to unemployment threat. However, when unemployment is viewed through the "lived unemployment rate" measure the pattern is reversed revealing that women are actually subject to greater numbers of jobless spells than are men. The male and female average "official unemployment rates" of 9.2\% and 8.5\% over the 1993-2001 period increased to $18.3 \%$ and $19.6 \%$ under the "live unemployment rate" measure with female rates of joblessness overtaking that of men (see Table 2).

This reversal of gender unemployment trends between these two measures of unemployment likely reflects the fact that women in the new economy are employed in greater proportions than men in more unstable contingent forms of work placing women in greater risk of job loss, although women may be unemployed for shorter periods of time

${ }^{2}$ The figures presented in the table from the years 1993 to 2001 are the ones that we currently have access to through SLID. 


\section{Assessing Employment Risk: New Dimensions in the Measurement of Unemployment}

as they move from one contingent job to another. Consequently, women are subject to higher levels of movement into and out of employment than are men, a phenomenon that is better captured in the "lived unemployment rate" measure.

Each of these measures of unemployment ("official" and "lived") fluctuated in tune with the robustness of the Canadian labour market "the earlier years recording higher incidents of unemployment as the job market only slowly rebounded from the recession of 199091." However, the overall pattern remained consistent, with the proportion of the population having experienced at least a bout of unemployment during the year out pacing average annual rates of unemployment by a ratio of about 2 to 1 . It is also interesting that the Canadian experience with unemployment, using annual averages, is high by international standards (McBride, 2000: 159-160; Jackson and Robinson, 2000).

An important lesson that can be culled from this analysis is the need for alternative indicators that are more sensitive to a society characterized by greater insecurity and risk. In the past, when the employment norm was considered to be full-time stable work, the use of static average unemployment rates as the standard measure of labour market attachment and security contained a strong underlying logic. In the new labour market featured by 'permanent restructuring', the rapid growth of employment contingency and employer-centred flexibility, new indicators, like our "lived unemployment rate", are better suited to detecting worker vulnerability in the new labour market. Of course, other alternative measures that attempt to capture not just unemployment but underemployment are also important in helping us track the impact of changes in the labour market (see for example: Cranford, Vosko and Zukewich, 2003; and Burke and Shields, 2000) Such alternative indicators are important tools for measuring employment risk and would be a significant tool in the struggle for progressive social policy reform. 
TABLE 1

"Official" and "Lived" Rates of Canadian Unemployment: 1993 - 2001

\begin{tabular}{|c|c|c|}
\hline Year & $\begin{array}{c}\text { Average Official } \\
\text { Unemployment Rate } \\
\text { (percentage) }\end{array}$ & $\begin{array}{l}\text { Lived Unemployment } \\
\text { Rate* (percentage) }^{*}\end{array}$ \\
\hline $1993-2001$ & 8.7 & 19.9 \\
\hline 1993 & 11.4 & 21.8 \\
\hline 1994 & 10.4 & 22.3 \\
\hline 1995 & 9.4 & 20.7 \\
\hline 1996 & 9.6 & 20.1 \\
\hline 1997 & 9.1 & 20.0 \\
\hline 1998 & 8.3 & 19.3 \\
\hline 1999 & 7.6 & 15.1 \\
\hline 2000 & 6.8 & 15.4 \\
\hline 2001 & 7.2 & 15.7 \\
\hline
\end{tabular}

* Percentages calculated from custom tabulations of the Survey of Labour and Income Dynamics. The "Lived Unemployment Rate" is calculated as the number of persons who were unemployed for some or all of the year divided by the number of persons who were in the labour force (i.e., employed or unemployed) for some or all of the year. 
Table 2

"Official" and "Lived" Rates of Canadian Unemployment, Male and Female: 1993 - 2001

\begin{tabular}{|c|c|c|c|c|}
\hline \multirow[t]{2}{*}{ Year } & \multicolumn{2}{|c|}{$\begin{array}{c}\text { Average Official } \\
\text { Unemployment Rate } \\
\text { (percentage) }\end{array}$} & \multicolumn{2}{|c|}{$\begin{array}{l}\text { Lived Unemployment } \\
\text { Rate* (percentage) }^{*}\end{array}$} \\
\hline & Male & Female & Male & Female \\
\hline 1993 - 2001 & 9.2 & 8.5 & 18.3 & 19.6 \\
\hline 1993 & 12.0 & 10.6 & 22.0 & 21.6 \\
\hline 1994 & 10.9 & 9.7 & 21.9 & 22.7 \\
\hline 1995 & 9.8 & 9.0 & 19.9 & 21.7 \\
\hline 1996 & 9.9 & 9.3 & 19.0 & 21.4 \\
\hline 1997 & 9.3 & 8.9 & 18.8 & 21.3 \\
\hline 1998 & 8.6 & 7.9 & 18.8 & 19.8 \\
\hline 1999 & 7.8 & 7.3 & 14.9 & 15.3 \\
\hline 2000 & 6.9 & 6.7 & 14.4 & 16.6 \\
\hline 2001 & 7.5 & 6.8 & 15.1 & 16.3 \\
\hline
\end{tabular}

* Percentages calculated from custom tabulations of the Survey of Labour and Income Dynamics. The "Lived Unemployment Rate" is calculated as the number of persons who were unemployed for some or all of the year divided by the number of persons who were in the labour force (i.e., employed or unemployed) for some or all of the year. 


\section{Assessing Employment Risk: New Dimensions in the Measurement of Unemployment}

\section{REFERENCES}

Barnet, Richard J. 1993. “The End of Jobs”, Harper's Magazine, September, pp. 47-52.

Beck, Ulrich. 1992. Risk Society: Towards a New Modernity. London: Sage.

Bennett, Ian. 2001. Fiscal/Economic Context: New Mandate of Government, Presentation by Associate Deputy Minister, Department of Finance, Government of Canada, Canadian Centre for Management Development, Ottawa, May 3.

Burke, Mike, Mooers, Colin \& John Shields. (eds.). 2000. Restructuring and Resistance: Canadian Public Policy in an Age of Global Capitalism. Halifax: Fernwood.

Burke, Mike \& John Shields. 2000. "Tracking Inequality in the New Canadian Labor Market". In Restructuring and Resistance: Canadian Public Policy in an Age of Global Capitalism. Mike Burke, Colin Mooers, and John Shields (eds.). Halifax: Fernwood, pp. 98-123.

Cranford, Cynthia, Vosko, Leah \& Nancy Zukewich. 2003. "Precarious Employment in the Canadian Labour Market: A Statistical Portrait." Just Labour, Volume 3, Fall, pp. 6-22.

Commission for Labor Cooperation. 1997. North American Labor Markets: A Comparative Profile. Dallar: Commission for Labor Cooperation.

Denny, Charlotte \& Larry Elliott. 2002. "Millions More Must Survive on \$1 a Day." The Guardian Weekly, June 27-July 3, pp. 16.

Elliott, Larry \& Mark Atkinson. 1999. "Protection for Workers Does Not Destroy Jobs, says OECD', The Guardian Weekly, July 1-7, pp. 8.

Elliott, Larry \& Mark Atkinson. 1998. The Age of Insecurity. London: Verso.

Government of Canada. 1994. A New Framework for Economic Policy. Ottawa:

Department of Finance, October.

Hahnel, Robin. 2005. "What Mainstream Economists Won't Tell You About Neoliberal Globalization." Socialist Studies: The Journal of the Society of Socialist Studies, Vol. 1, No. 1, pp. 5-30. 
International Labour Organization (ILO). 2004a. Economic Security for a Better World. Geneva: International Labour Office.

ILO. 2004b. "Global Employment Trends 2004: Record Joblessness, but Relief may be on the Way." World of Work, No. 50, March, pp. 10-13.

ILO. 2003. "Uncertain Prospects: New ILO Report Paints Grim Picture of World Employment.” World of Work, No. 46, March, pp. 8-11.

ILO. 2001. World Labour Report 2001: Life at Work in the Information Economy. Geneva: International Labour Office.

ILO. 1998. World Employment Report 1998-99: Employability in the Global Economy, How Training Matters. Geneva: International Labour Office.

Jackson, A. and D. Robinson. 2000. Falling Behind: The State of Working Canada, 2000. Ottawa: Canadian Centre for Policy Alternatives.

McBride, Stephen. 2000. "Policy from What? Neoliberal and Human-Capital Theoretical Foundations of Recent Canadian Labor-Market Policies." In Restructuring and Resistance: Canadian Public Policy in an Age of Global Capitalism. Mike Burke, Colin Mooers and John Shields (eds.). Halifax: Fernwood Publishing, pp. 159-177.

McBride, Stephen. 1992. Not Working: State, Unemployment and Neo-Conservatism in Canada. Toronto: University of Toronto Press.

OECD. (1994). The OECD Jobs Study: Facts, Analysis, Strategies. Paris: OECD.

Wolman, William \& Anne Colamosca. 1997. The Judas Economy: The Triumph of Capital and the Betrayal of Work. New York: Addison-Wesley Publishing.

Yates, Michael D. 2003. Naming the System: Inequality and Work in the Global Economy. New York: Monthly Review Press. 